\title{
Effects of 12 weeks of high intensity circuit training on abdominal fat, physical fitness, blood lipids, and insulin resistance in middle-aged obese women
}

\author{
Won-Beom Park, Hyun-Seok Cho, \& Man-Gyoon Lee* \\ Kyung Hee University
}

\begin{abstract}
[Purpose] The study examined the effects of a 12-week high intensity circuit training (HICT) on abdominal fat, physical fitness, blood lipids, and insulin resistance in middle-aged obese women. [Methods] Thirty obese women, aged 32-48 yrs, were recruited and randomly assigned to either HICT group (TR; $n=15)$ or control group (CON; $n=15)$. Subjects in the TR group participated in HICT of which resistance exercise and aerobic exercise were performed with a duration of $40 \mathrm{~min} / \mathrm{session}$ and 3 sessions/wk for 12 weeks, whereas subjects in the CON group were asked to maintain their normal life patterns. Dependent variables included abdominal fat area, body composition, physical fitness, blood lipids profiles, and insulin resistance index. Analysis of variance with repeated measures with Bonferroni corrections was used to compare the outcomes between two groups. [Results] Main findings of the present study were as follows: 1) compared to the CON group, the TR group had significant reductions in overall (i.e., body mass index and percent body fat) and abdominal obesity (i.e., waist circumference, total abdominal fat area, visceral fat area, subcutaneous fat area, and visceral fat area-subcutaneous fat area ratio), 2) compared to the CON group, the TR group had significant improvements in health-related physical fitness (i.e., muscular strength, muscular endurance, muscle power, flexibility, balance, and cardiorespiratory endurance), and 3) compared to the CON group, the TR group had significant improvements in fasting lipids, glucose, insulin, and insulin resistance. [Conclusions] The current findings of the study suggested that HICT would be an effective exercise intervention to improve metabolic complications associated with obesity and poor physical fitness in obese middle-aged women.
\end{abstract}

Key words: High intensity exercise, Circuit training, Abdominal fat, Blood lipid, Insulin resistance

\begin{abstract}
서 론
비만은 전 세계적으로 심각한 사회·경제적 문제를 야 기하는 질병으로서 세계 성인 인구의 $13 \%$ 가 비만에 해 당된다(WHO, 2018). 국내의 경우는 상황이 더 심각하 여 2016년 시점으로 국내의 19세 이상 성인의 비만율이 $34.9 \%$ 로 조사되었으며, 여성의 비만율은 $27.6 \%$ 로 남성
\end{abstract}

논문 투고일 : 2019. 04. 01.

논문 수정일 : 2019. 05. 03.

게재 확정일 : 2019. 05. 09 .

* 교신저자 : 이만균(mlee@ khu.ac.kr).
(41.6\%)에 비하여 낮지만 최근 6년간의 비만율 중 가장 높은 수치를 보이고 있다(National Health Insurance Service, 2017). 여성의 비만율이 증가되는 원인은 연령 이 증가될수록 신체활동량이 감소되고, 여성 호르몬인 에 스트로겐의 감소로 인하여 제지방량이 감소되며, 과도한 영양 섭취로 인하여 복부 지방이 증가되기 때문이라고 보 고된 바 있다(Lizcano \& Guzmán, 2014).

일반적인 비만도 문제이지만, 특히 복부 지방이 증가 되는 것은 더 심각한 문제를 초래한다. 증가된 복부 지 방은 당뇨병과 이상지질혈증 등의 대사질환과 각종 심 
혈관질환을 일으키는 주원인이 된다(Nordström et al., 2016). 복부 비만을 해결하기 위한 운동의 강도와 관련 하여 Lee et al. (2012)은 체내 전반적인 체지방률을 감 소시키는데 저강도 $\left(\mathrm{VO}_{2}\right.$ peak $\left.50 \%\right)$ 의 장시간 운동이 효 과적이지만, 내장 지방을 효과적으로 감소시키기 위하여 고강도의 운동이 필요하다고 주장하였다. 이와 유사하게 Coker et al. (2009)은 저강도 $\left(\mathrm{VO}_{2}\right.$ peak $\left.50 \%\right)$ 운동에 비하여 고강도 $\left(\mathrm{VO}_{2}\right.$ peak $\left.75 \%\right)$ 운동이 복부 내장 지방량 의 감소에 더 효과적이었다고 보고한 바 있다.

복부 내장 지방을 효과적으로 감소시키기 위하여 고강 도의 운동이 권고된다고 해서 대표적인 유산소운동 유형 인 달리기를 고강도로 실시하는 것은 몇 가지 문제점을 내 포하고 있다. 달리기는 주로 하지 (lower extremity)만 단 련시키고, 단순한 동작이 반복되어 흥미성이 떨어지며, 무를과 발목에 하중이 집중되어 부상 위험도가 커질 수 있다. 그럼에도 불구하고 과거에는 중년 여성의 복부 지 방을 개선하기 위한 운동방법으로 대부분 유산소 운동에 대한 연구가 주를 이루었고, 이를 통한 복부 내장 지방을 효과적으로 감소시키기 위한 연구가 지속되었다(Irving et al., 2008). 최근 유산소운동과 함께 저항성운동을 추 가하는 것이 복부비만에 효과적이라고 보고되었고, 이와 같은 복합운동을 실시하기 위한 방안으로 고강도 순환운 동(high-intensity circuit training: HICT)이 제시되었 다(Willis et al., 2012). HICT는 유산소운동과 저항성 운동을 병행하여 순환식으로 실시할 수 있는 운동으로서 짧은 시간에 다양한 운동 효과를 얻을 수 있다. 지방의 감 소와 심폐지구력의 향상이라는 유산소운동의 효과에 더 하여 제지방의 증가와 근력의 향상이라는 저항성운동의 효과를 동시에 얻을 수 있으며, 복부 지방의 감소에도 큰 도움이 된다고 보고되었다(Takeshima et al., 2004).

중년 여성을 대상으로 중강도와 고강도의 운동을 비 교한 Zhang et al.(2015)의 연구에서 두 가지 운동 강도 모두 신체구성의 긍정적인 변화를 유도하였지만, 내장 지방은 고강도 운동에서만 유의하게 감소되는 것으로 나타났다. 이에 더하여 연령이 높아질수록 복부 내장 지 방을 개선하기 위해서는 중강도 보다 고강도의 순환운동 이 유의한 감소를 가져오는 것으로 보고되었다(RomeroArenas et al., 2013). 따라서 HICT는 복부 내장 지방 개 선에 매우 효과적인 것으로 판단된다. 또한, 순환운동은 그룹운동 (group exercise: GX)으로도 진행이 가능하고, 이에 다수 인원의 동시 참여를 통한 흥미성이 높아져 지
속적인 운동 참여를 유도하기에 적합한 것으로 보고되 었다(Solanki et al., 2015).

이상에서 살펴본 바와 같이 체내에 과도하게 축적된 복부 내장 지방은 각종 생활습관병의 주원인이 되며, 내 장 지방은 고강도의 순환운동을 통하여 개선될 것으로 기 대된다. 그러나 비만율이 증가되고 있는 중년 여성을 대 상으로 $\mathrm{HICT}$ 가 복부 지방과 관련 변인에 미치는 영향을 종합적으로 규명한 연구가 아직 매우 부족한 실정이다. 이에 따라 HICT를 통한 복부 비만 지표, 당뇨병과 고지 혈증 지표, 그리고 체력에 미치는 영향을 종합적으로 파 악하는 연구가 필요하며, 특히 타당도 높은 방법으로 복 부 지방면적을 측정하여 분석하는 연구가 필요하다. 또한 기존의 선행 연구는 대상자의 개개인에 따른 체력을 고려 하지 못하고 주로 GX 형태로 순환운동을 처치하였지만, 이 연구에서는 대상자 1 명씩 개별적 트레이닝 $(\mathrm{PT})$ 을 진 행하여 운동 중재의 효과를 높이고자 하였다. 이 연구에 서는 중년 비만 여성을 대상으로 12 주간의 $\mathrm{HICT}$ 가 복부 지방, 신체구성, 체력, 혈중 지질, 그리고 인슐린 저항성 에 미치는 영향을 규명하고자 하였다.

\section{연구방법}

\section{연구 대상자}

이 연구의 대상자는 중년 비만 여성으로서, 체지방률 이 $30 \%$ 이상이고, 최근 6 개월 내에 체계적인 운동 경험 이 없으며, 각종 질환이 없는 자 30 명을 선정하였다. 연 구 대상자의 수를 결정하기 위하여 Kim et al.(2012)의 내장 지방면적을 참고하였고, 효과크기 0.5 , 유의수준 $(\alpha)$ $5 \%$, 그리고 검정력 $(\beta)$ 80\%를 적용해서 $\mathrm{G}^{*}$ Power 3.1 프로그램을 이용하여 필요한 대상자 수를 산출한 결과 26 명이었으며, 탈락률을 고려하여 총 30 명을 모집인원 으로 정하였다. S시 G구 지역에 전단지 및 포스터를 부 착 또는 배포하여 대상자를 모집하였으며, 선정된 30명 의 인원을 운동집단과 통제집단에 각각 15 명씩 무선할 당하였다. 이 연구가 시작되기 전 연구 목적과 절차에 대 하여 설명하였고, 이를 이해하고 자발적으로 참여하고자 하는 자로부터 검사동의서를 받은 후 연구에 참여하도 록 하였다. 이 연구에 참여한 대상자의 신체적 특성은 〈Table 1〉과 같다. 
Table 1. Physical characteristics of subjects

$(\mathrm{Mean} \pm \mathrm{SD})$

\begin{tabular}{lccc}
\hline \hline Variables & TR & CON & $p$ \\
\hline Age $(\mathrm{yrs})$ & $40.93 \pm 6.06$ & $39.13 \pm 4.29$ & .356 \\
\hline Height $(\mathrm{cm})$ & $160.19 \pm 4.95$ & $162.83 \pm 5.91$ & .195 \\
\hline Body weight $(\mathrm{kg})$ & $68.05 \pm 8.98$ & $68.49 \pm 5.19$ & .871 \\
\hline BMI $\left(\mathrm{kg} \cdot \mathrm{m}^{-2}\right)$ & $26.56 \pm 3.13$ & $25.85 \pm 1.64$ & .443 \\
\hline Fat mass $(\mathrm{kg})$ & $23.27 \pm 4.73$ & $22.38 \pm 2.38$ & .520 \\
\hline \%BF $(\%)$ & $34.08 \pm 2.84$ & $32.61 \pm 1.55$ & .088 \\
\hline \hline
\end{tabular}

BMI: Body mass index, \%BF: Percent body fat.

\section{측정 항목과 방법}

사전검사를 위하여 모든 대상자는 12 시간 이상의 공 복 상태를 유지하고, 8시간 이상의 숙면을 취한 후 실험 일 오전 7시에 실험실을 방문하였다. 본 연구에서 복부 지방 검사, 체격과 신체구성 검사, 체력 검사, 그리고 채 혈과 혈액성분 분석을 실시하였다. 12 주간의 중재 후 사 전검사와 동일한 방법으로 사후검사를 실시하였다.

\section{1) 복부 지방 검사}

복부 지방의 면적은 $\mathrm{S}$ 시 $\mathrm{Y}$ 구에 위치한 $\mathrm{W}$ 병원의 영상 의학과에서 $\mathrm{CT}$ (Supria, Hitachi, 일본)를 이용하여 측정 하였다. 제대수준의 횡단면 부위에서 Hounsfield number가 - $150 \sim-50$ 사이의 조직을 지방으로 간주하여 총 복부 지방면적 (total abdominal fat area: TAFA)을 구하 였다. 복부와 배부의 복막을 경계로 안쪽에 해당하는 내 장 지방면적 (visceral fat area: VFA)과 바깥쪽에 해당하 는 피하 지방면적 (subcutaneous fat area: SFA)을 구했 으며〈Fig. 1〉, 이 결과를 이용하여 $\mathrm{VFA}$ 에 대한 $\mathrm{SFA}$ 의 비율(visceral fat area/subcutaneous fat area: V/S) 을 산출하였다.

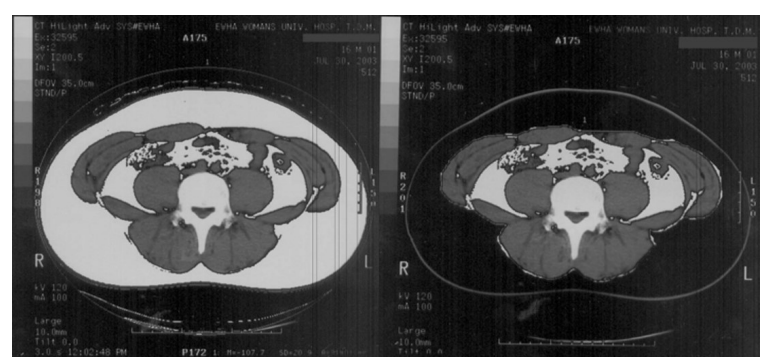

Fig 1. Subcutaneous fat area(left) and visceral fat area(right).

\section{2) 체격과 신체구성 검사}

신장은 수동식 신장계 (Samhwa, 한국)를 이용하여 측 정하였고, 체중은 전자식 체중계 (DW- $150, \mathrm{CAS}$, 한국) 를 이용하여 측정하였으며, 체중 $(\mathrm{kg})$ 을 신장의 제곱 $\left(\mathrm{m}^{2}\right)$ 으로 나누어 체질량지수(body mass index: BMI)를 산 출하였다. 허리둘레는 줄자를 이용하여 배꼽 높이에서 수 평으로 측정하였고, 엉덩이둘레는 엉덩이 중 가장 튀어나 온 부위를 수평으로 측정하였으며, 이 결과를 이용하여 허 리엉덩이둘레 비율 (waist-hip ratio: WHR)을 산출하였 다. 이후 생체전기저항법 측정 장비 (X-scan Plus-II, 자 원메디칼, 한국)를 이용하여 체지방량, 체지방률, 그리고 제지방량을 측정하였다.

\section{3) 체력 검사}

국민체력실태조사(Ministry of Culture, Sports and Tourism, 2017)의 검사항목인 악력, 제자리멀리뛰기, 윗 몸일으키기, 그리고 앉아윗몸앞으로굽히기를 실시하였 으며, 이에 더하여 평형성을 평가하기 위하여 눈감고외발 서기, 그리고 심폐지구력을 평가하기 위하여 $\mathrm{YMCA}$ 스 텝테스트(Golding, 2000)를 실시하였다.

악력은 악력계(T.K.K. 5401, Takei, 일본)를 이용해 서 2 회 측정하여 높은 수치를 $0.1 \mathrm{~kg}$ 단위로 기록하였 고, 윗몸일으키기는 1 분간 실시한 횟수를 기록하였으며, 제자리멀리뛰기는 2 회 측정하여 높은 수치를 $\mathrm{cm}$ 단위로 기록하였다. 앉아윗몸앞으로굽히기는 좌전굴계 (FT-7300, Donghwa, 한국)를 이용해서 2회 측정하여 높은 수치를 $0.1 \mathrm{~cm}$ 단위로 기록하였고, 눈감고외발서기는 오른쪽 다 리로 서서 2회 측정하여 높은 수치를 0.1 초 단위로 기록 하였다. YMCA 스텝테스트는 높이 $30.5 \mathrm{~cm}$ 의 스텝박스 를 $96 \mathrm{bpm}$ 의 리듬에 맞춰 3 분간 오르내리게 한 후 1 분 간 측정한 심박수를 다음의 추정식 (Korea Institute of Sport Science, 2014)에 대입하여 최대산소섭취량을 산 출하였다(Lee et al., 2008).

$$
\begin{aligned}
\mathrm{VO}_{2} \max = & 54.337-(0.185 \times \text { 연령 }) \\
& +(0.097 \times \text { 신장 }) \\
& -(0.246 \times \text { 체중 }) \\
& -(0.122 \times 1 \text { 분간 회복기 심박수 })
\end{aligned}
$$

4) 채혈 및 혈액성분 분석

체격과 신체구성의 측정 후 전문 간호사가 1 회용 주사 
기를 이용하여 대상자의 상완 주정맥 (antecubital vein) 에서 $15 \mathrm{ml}$ 의 정맥혈을 채취하였다. 채취한 혈액을 각각 의 분석항목에 따라 항응고제 처리된 튜브 또는 처리되 지 않은 튜브에 넣어 원심분리기를 이용하여 $3,000 \mathrm{rpm}$ 으로 10 분간 원심분리하였다. 혈장 (plasma) 또는 혈청 (serum)을 뽑아 보관 튜브에 넣어 분석 시까지 $-70^{\circ} \mathrm{C}$ 의 냉동고에서 보관하였고, 이를 (주) $\mathrm{G}$ 의료재단에 의뢰하여 혈액 성분을 분석하였다.

혈청 샘플을 이용하여 혈중 지질관련 변인인 총 콜 레스테롤(total cholesterol: TC), 중성지방 (triglyceride: TG), 고밀도 지단백 콜레스테롤 (high-density lipoprotein cholesterol: HDL-C), 그리고 저밀도 지단백 콜 레스테롤(low-density lipoprotein cholesterol: LDLC)을 분석하였다. TC는 direct assay로 cholesterol oxidase를 이용한 화학 반응 원리로 분석하였다. $\mathrm{TG}$ 는 글리 세롤 소거법을 이용하여 자동분석기(Olympus AU 2700, Olympus, 일본)로 분석하였다. HDL-C는 direct assay 로 계면활성제를 이용하여 용해시킨 후 효소반응에 의한 결과를 정색측정 하였다. $\mathrm{LDL}-\mathrm{C}$ 는 direct assay로 과산 화수소 생성 후, 정색반응을 일으켜 비색측정 하였다.

혈장 샘플을 이용하여 인슐린 저항성 지표인 공복 혈당 (fasting plasma glucose: FPG)과 공복 인슐린 (fasting plasma insulin: FPI)을 측정하였다. FPG는 자동분석기 (Olympus AU 2700, Olympus, 일본)를 이용하여 Hexokinase 방법으로 분석하였고, FPI는 면역분석장비(Elecsys, Roche, 스위스)를 이용하여 전기화학적 발광면역 분석법 (electrochemiluminescence immunoassay)으로 분석 하였으며, FPG와 FPI를 다음의 공식 (Matthews et al., 1985)에 대입하여 HOMA-IR(homeostasis model of assessment for insulin resistance)을 산출하였다.

HOMA-IR =

$\mathrm{FPI}\left(\mu \mathrm{U} \cdot \mathrm{ml}^{-1}\right) \times \mathrm{FPG}(\mathrm{mmol} \cdot \ell-1) / 22.5$

\section{운동 중재 방법}

운동집단의 대상자는 12 주간 저항성운동과 유산소 운동으로 구성된 순환운동 프로그램에 참여하였다. 이 연 구에서 적용한 운동 프로그램은 $\operatorname{ACSM}(2009)$ 의 요일별 저항성 운동 방법 가이드라인 및 Kim et al.(2014)과 Klika \& Jordan(2013)의 체중을 이용한 순환운동 방법
을 참고하여 구성하였다. 월(화)요일에는 가슴과 어깨 위 주의 저항성운동(bench press, pec fly, shoulder press, side lateral raise)과 burpee test, side step, alternate jump, 그리고 jumping jack으로 구성된 유산소운 동을 실시하였고, 수(목)요일에는 등과 팔 위주의 저항 성운동(lat pull down, seated row, cable press down, dumbbell curl)과 mountain climbing, high knees, burpee test, 그리고 side step으로 구성된 유산소운동을 실시하였으며, 금(토)요일에는 하체와 복부 위주의 저항 성운동 (squat, split squat, sit up, leg raise)과 alternate jump, jumping jack, mountain climbing, 그리고 high knees로 구성된 유산소운동을 실시하였다. 운동 강도는 저항성 운동의 경우 $1 \mathrm{RM}$ (repetition maximum) 의 $80 \%$ 로 설정하였고, 유산소운동과 체중부하운동의 경 우 HRR(heart rate reserve)의 80\%로 설정하였다.

1 일 운동 시간은 준비운동 10 분, 본운동 40 분, 정리운 동 10 분, 총 60 분으로 진행하였다. 준비운동과 정리운동 은 각각 5 분의 스트레칭과 5 분의 걷기로 구성하여 10 분씩 진행하였고, 본운동은 총 4 세트로 진행하였다. 한 세트당 체중부하운동을 포함한 저항성운동 4종목과 유 산소운동 4 종목, 총 8 종목을 교차로 진행하였다. 단계별 로 운동시간과 휴식시간을 조정하여 총 운동량을 점차적 으로 증가시켜 나갔다. 적응단계(1 4주)에서는 종목당 운동시간을 30 초, 세트 간 휴식시간을 4 분 40 초로 설정 하였고, 향상단계 (5 8주)에서는 종목당 운동시간을 40 초, 세트 간 휴식시간을 3 분 20 초로 설정하였으며, 숙련 단계 (9 12주)에서는 종목당 운동시간을 50초, 세트 간 휴식시간을 2 분으로 설정하여 실제 운동시간을 점차적으 로 증가시켰다. 종목당 이동시간은 10 초로 제한하였다. 운동 중 심박수 측정기 (H10, Polar, 핀란드)를 이용하여 목표 심박수를 유지하도록 하였고, 2 주일에 1 회씩 $1 \mathrm{RM}$ 을 측정하여 저항성운동의 강도를 유지하도록 하였다. 운 동 프로그램은 전문 트레이너 1 인이 대상자별 개인 트레 이닝 형태로 진행하였으며, 평균 참석률은 36회 중 33회 (91.67\%)로 조사되었다.

한편, 통제집단의 대상자는 동일한 중재 기간 동안 평 소의 생활습관을 그대로 유지하도록 하였다. 두 집단 모 두 12 주간의 중재 기간 동안 신체활동습관과 식이습관 을 최대한 동일하게 유지하도록 지속적으로 전화 및 문 자를 통하여 독려하였으며, 두 집단 모두에서 중재 기간 중 탈락자가 없었다. 


\section{자료처리 방법}

이 연구에서 얻은 모든 데이터는 SPSS PC+ for Windows (version 23.0)를 이용하여 분석하였다. 각 종 속변인의 기술통계량을 제시하기 위하여 평균(Mean)과 표준편차(standard deviation: SD)를 산출하였다. 두 집 단 간, 그리고 두 검사 간 평균 차이를 동시에 분석하기 위 하여 반복 이원변량분석을 실시하였다. 집단의 주효과, 검 사의 주효과, 또는 집단과 검사의 상호작용이 유의한 경 우 각 집단 내 두 검사 간의 차이는 종속 t-검증으로, 그리 고 각 검사 내 두 집단 간의 차이는 독립 $\mathrm{t}$-검증으로 분석 하였으며, Bonferroni correction을 하였다. 운동 중재에

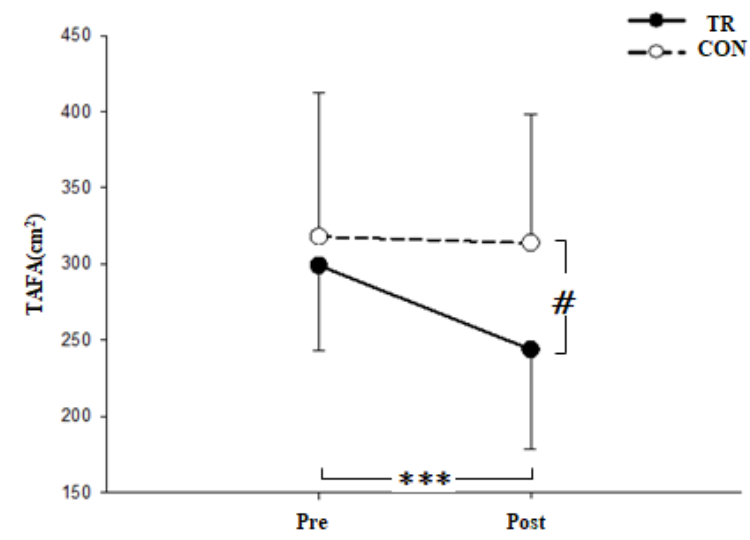

Fig. 2. Changes in total abdominal fat area
따른 각 종속변인의 변화량 간의 관계를 파악하기 위하 여 상관분석을 실시하여 피어슨의 상관계수 $(\mathrm{r})$ 를 산출하 였다. 모든 통계분석의 유의수준 $(\alpha)$ 은 .05로 설정하였다.

\section{연구결과}

복부 지방과 관련하여 TAFA, VFA, SFA, 그리고 $\mathrm{V} / \mathrm{S}$ 모두 집단과 검사의 상호작용이 유의하게 나타났다. 또 한 운동집단의 TAFA, $\mathrm{VFA}, \mathrm{SFA}$, 그리고 $\mathrm{V} / \mathrm{S}$ 가 유의하 게 감소되었다〈Fig. 2, Fig. 3, Table 2〉.

체격 및 신체구성과 관련하여 제지방량을 제외한 체

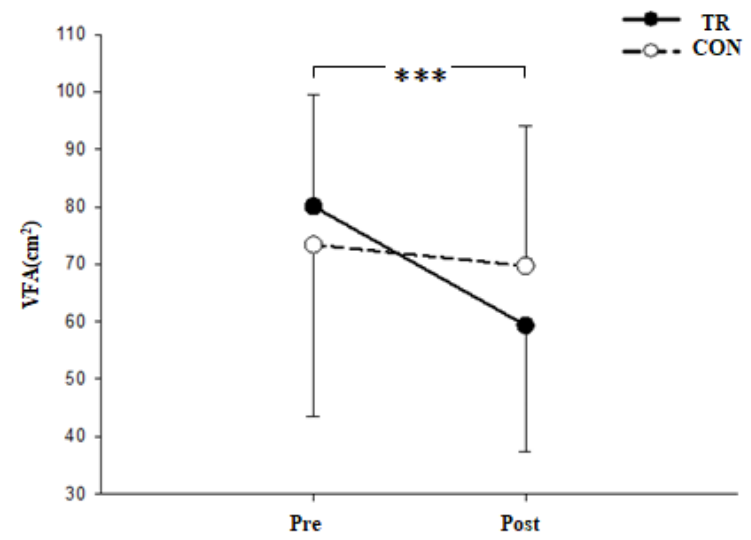

Fig. 3. Changes in visceral fat area

Table 2. Changes in abdominal fat area

(Mean \pm SD)

\begin{tabular}{|c|c|c|c|c|c|c|c|}
\hline \multirow{2}{*}{ Variables } & \multirow{2}{*}{ Groups } & \multicolumn{2}{|c|}{ Tests } & \multirow{2}{*}{\multicolumn{2}{|c|}{$\Delta \%$}} & & \multirow{2}{*}{$p$} \\
\hline & & Pre & Post & & & & \\
\hline \multirow{2}{*}{$\begin{array}{l}\text { Total abdominal fat area } \\
\left(\mathrm{cm}^{2}\right)\end{array}$} & $\mathrm{TR}$ & $299.16 \pm 55.74$ & $243.83 \pm 65.32^{\#}$ & $* * *$ & -18.50 & \multirow{2}{*}{$\begin{array}{c}\text { Group } \\
\text { Test } \\
\text { Group } \times \text { Test }\end{array}$} & \multirow{2}{*}{$\begin{array}{l}.113 \\
.000^{++1} \\
.000^{+1+}\end{array}$} \\
\hline & $\mathrm{CON}$ & $317.99 \pm 94.09$ & $313.90 \pm 84.29$ & & -1.29 & & \\
\hline \multirow{2}{*}{$\begin{array}{l}\text { Visceral fat area } \\
\left(\mathrm{cm}^{2}\right)\end{array}$} & TR & $80.08 \pm 19.53$ & $59.33 \pm 21.99$ & $* * *$ & -25.91 & \multirow{2}{*}{$\begin{array}{c}\text { Group } \\
\text { Test } \\
\text { Group } \times \text { Test }\end{array}$} & \multirow{2}{*}{$\begin{array}{l}.829 \\
.000^{+1+1+} \\
.000^{+1+}\end{array}$} \\
\hline & $\mathrm{CON}$ & $73.41 \pm 29.88$ & $69.74 \pm 24.24$ & & -5.00 & & \\
\hline \multirow{2}{*}{$\begin{array}{l}\text { Subcutaneous fat area } \\
\left(\mathrm{cm}^{2}\right)\end{array}$} & TR & $219.08 \pm 47.45$ & $184.50 \pm 54.66^{\#}$ & *** & -15.78 & \multirow{2}{*}{$\begin{array}{c}\text { Group } \\
\text { Test } \\
\text { Group } \times \text { Test }\end{array}$} & \multirow{2}{*}{$\begin{array}{l}.062 \\
.001^{++} \\
.001^{++}\end{array}$} \\
\hline & $\mathrm{CON}$ & $244.58 \pm 71.05$ & $244.16 \pm 68.92$ & & -0.17 & & \\
\hline \multirow{2}{*}{$\begin{array}{l}\text { Visceral fat area/ } \\
\text { subcutaneous fat area }\end{array}$} & $\mathrm{TR}$ & $0.38 \pm 0.11$ & $0.34 \pm 0.13$ & $* *$ & -10.53 & \multirow{2}{*}{$\begin{array}{c}\text { Group } \\
\text { Test } \\
\text { Group } \times \text { Test }\end{array}$} & \multirow{2}{*}{$\begin{array}{l}.134 \\
.002^{++} \\
.040^{+}\end{array}$} \\
\hline & $\mathrm{CON}$ & $0.30 \pm 0.09$ & $0.29 \pm 0.09$ & & -3.33 & & \\
\hline
\end{tabular}

\#: Significant difference between two groups.

${ }^{* *} p<.01,{ }^{* * *} p<.001$ : Significant difference between pre and post-test.

${ }^{+} p<.05,{ }^{++} p<.01,{ }^{+++} p<.001$ : Significant main effect and/or interaction. 
중, 체질량지수, 체지방량, 체지방률, 허리둘레, 엉덩이 둘레, 그리고 $\mathrm{WHR}$ 에서 집단과 검사의 상호작용이 유의 하게 나타났다. 또한 운동집단의 체중, 체질량지수, 체지 방량, 제지방량, 허리둘레, 그리고 $\mathrm{WHR}$ 이 유의하게 감 소되었으며, 체지방률은 운동집단과 통제집단에서 유의 하게 감소되었다〈Table 3 〉.

체력과 관련하여 우악력을 제외한 좌악력, 윗몸일으 키기, 제자리멀리뛰기, 앉아윗몸앞으로굽히기, 눈감고외 발서기, 그리고 최대산소섭취량에서 집단과 검사의 상호 작용이 유의하게 나타났다. 또한 운동집단의 좌악력, 윗 몸일으키기, 제자리멀리뛰기, 앉아윗몸앞으로굽히기, 그 리고 눈감고외발서기가 유의하게 증가되었으며, 최대산 소섭취량은 운동집단과 통제집단 모두에서 유의하게 증 가되었다〈Table 4〉.
혈중 지질과 관련하여 $\mathrm{LDL}-\mathrm{C}$ 를 제외한 $\mathrm{TC}, \mathrm{TG}$, 그 리고 $\mathrm{HDL}-\mathrm{C}$ 에서 집단과 검사의 상호작용이 유의하게 나타났다. 또한 운동집단의 $\mathrm{TC}$ 와 $\mathrm{TG}$ 가 유의하게 감소 되었고, 통제집단의 $\mathrm{HDL}-\mathrm{C}$ 가 유의하게 감소되었다 $\langle$ Table 5〉.

인슐린 저항성과 관련하여 FPG, FPI, 그리고 HOMA$\mathrm{IR}$ 에서 집단과 검사의 상호작용이 유의하게 나타났다. 운동집단의 FPG, FPI, 그리고 HOMA-IR이 유의하게 감소되었다〈Table 6〉.

운동집단에서 나타난 종속변인의 변화량 간의 상관관 계를 분석한 결과 $\mathrm{TAFA}, \mathrm{VFA}$, 그리고 $\mathrm{SFA}$ 가 체지방률 과 각각 유의한 정적 상관관계 $(\mathrm{r}=.648, \mathrm{r}=.548, \mathrm{r}=$ $626)$ 를 보였고, $\mathrm{VO}_{2} \max$ 와는 부적 상관관계 $(\mathrm{r}=-.727$, $r=-.583, r=-.717)$ 를 보였다〈Table 7〉.

Table 3. Changes in physique and body composition

$(\mathrm{Mean} \pm \mathrm{SD})$

\begin{tabular}{|c|c|c|c|c|c|c|c|}
\hline \multirow{2}{*}{ Variables } & \multirow{2}{*}{ Groups } & \multicolumn{2}{|c|}{ Tests } & \multirow{2}{*}{\multicolumn{2}{|c|}{$\Delta \%$}} & & \multirow[b]{2}{*}{$p$} \\
\hline & & Pre & Post & & & & \\
\hline \multirow{2}{*}{$\begin{array}{l}\text { Body weight } \\
\text { (kg) }\end{array}$} & TR & $69.9 \pm 10.7$ & $66.1 \pm 10.2$ & $* * *$ & -5.44 & \multirow{2}{*}{$\begin{array}{c}\text { Group } \\
\text { Test } \\
\text { Group } \times \text { Test }\end{array}$} & \multirow{2}{*}{$\begin{array}{l}.623 \\
.000^{+1+} \\
.000^{+1+}\end{array}$} \\
\hline & $\mathrm{CON}$ & $69.6 \pm 6.9$ & $69.5 \pm 6.1$ & & -0.14 & & \\
\hline \multirow{2}{*}{$\begin{array}{l}\text { Body mass index } \\
\left(\mathrm{kg} \cdot \mathrm{m}^{-2}\right)\end{array}$} & $\mathrm{TR}$ & $27.3 \pm 4.1$ & $25.8 \pm 3.9$ & $* * *$ & -5.49 & \multirow{2}{*}{$\begin{array}{c}\text { Group } \\
\text { Test } \\
\text { Group } \times \text { Test }\end{array}$} & \multirow{2}{*}{$\begin{array}{l}.881 \\
.000^{+1+} \\
.000^{+1+}\end{array}$} \\
\hline & $\mathrm{CON}$ & $26.4 \pm 2.1$ & $26.4 \pm 2.2$ & & 0.00 & & \\
\hline \multirow{2}{*}{$\begin{array}{l}\text { Fat mass } \\
(\mathrm{kg})\end{array}$} & $\mathrm{TR}$ & $24.4 \pm 6.0$ & $21.4 \pm 5.8$ & $* * *$ & -12.30 & \multirow{2}{*}{$\begin{array}{c}\text { Group } \\
\text { Test } \\
\text { Group } \times \text { Test }\end{array}$} & \multirow{2}{*}{$\begin{array}{l}.894 \\
.000^{+1+} \\
.002^{++}\end{array}$} \\
\hline & $\mathrm{CON}$ & $23.1 \pm 3.4$ & $22.3 \pm 2.5$ & & -3.46 & & \\
\hline \multirow{2}{*}{$\begin{array}{l}\text { Percent body fat } \\
(\%)\end{array}$} & $\mathrm{TR}$ & $34.6 \pm 3.3$ & $31.9 \pm 3.9$ & $* * *$ & -7.80 & \multirow{2}{*}{$\begin{array}{c}\text { Group } \\
\text { Test } \\
\text { Group } \times \text { Test }\end{array}$} & \multirow{2}{*}{$\begin{array}{l}.487 \\
.000^{++1} \\
.014^{+}\end{array}$} \\
\hline & $\mathrm{CON}$ & $33.0 \pm 1.9$ & $32.0 \pm 1.8$ & * & -3.03 & & \\
\hline \multirow{2}{*}{$\begin{array}{l}\text { Fat-free mass } \\
(\mathrm{kg})\end{array}$} & $\mathrm{TR}$ & $41.6 \pm 4.5$ & $41.0 \pm 4.3$ & & -1.44 & \multirow{2}{*}{$\begin{array}{c}\text { Group } \\
\text { Test } \\
\text { Group } \times \text { Test }\end{array}$} & \multirow{2}{*}{$\begin{array}{l}.326 \\
.098 \\
.054\end{array}$} \\
\hline & $\mathrm{CON}$ & $42.7 \pm 3.4$ & $42.7 \pm 3.1$ & & 0.00 & & \\
\hline \multirow{2}{*}{$\begin{array}{l}\text { Waist circumference } \\
(\mathrm{cm})\end{array}$} & $\mathrm{TR}$ & $89.0 \pm 7.8$ & $82.1 \pm 8.6 \#$ & $* *$ & -7.75 & \multirow{2}{*}{$\begin{array}{c}\text { Group } \\
\text { Test } \\
\text { Group } \times \text { Test }\end{array}$} & \multirow{2}{*}{$\begin{array}{l}.031^{+} \\
.000^{+1+} \\
.001^{++}\end{array}$} \\
\hline & $\mathrm{CON}$ & $92.5 \pm 9.0$ & $92.2 \pm 8.7$ & & -0.32 & & \\
\hline \multirow{2}{*}{$\begin{array}{l}\text { Hip circumference } \\
(\mathrm{cm})\end{array}$} & $\mathrm{TR}$ & $100.7 \pm 6.3$ & $99.7 \pm 6.3$ & & -0.99 & \multirow{2}{*}{$\begin{array}{c}\text { Group } \\
-\quad \text { Test } \\
\text { Group } \times \text { Test }\end{array}$} & \multirow{2}{*}{$\begin{array}{l}.289 \\
.928 \\
.027^{+}\end{array}$} \\
\hline & $\mathrm{CON}$ & $102.1 \pm 6.3$ & $103.2 \pm 6.1$ & & +1.08 & & \\
\hline \multirow{2}{*}{ Waist-hip ratio } & $\mathrm{TR}$ & $0.9 \pm 0.0$ & $0.8 \pm 0.1 \#$ & $* *$ & -11.11 & \multirow{2}{*}{$\begin{array}{c}\text { Group } \\
\text { Test } \\
\text { Group } \times \text { Test }\end{array}$} & \multirow{2}{*}{$\begin{array}{l}.005^{++} \\
.000^{+1+} \\
.005^{++}\end{array}$} \\
\hline & $\mathrm{CON}$ & $0.9 \pm 0.0$ & $0.9 \pm 0.0$ & & 0.00 & & \\
\hline
\end{tabular}

\#: Significant difference between two groups.

${ }^{*} p<05,{ }^{* *} p<.01,{ }^{* * *} p<.001$ : Significant difference between pre and post-test.

${ }^{+} p<.05,{ }^{++} p<.01,{ }^{+++} p<.001$ : Significant main effect and/or interaction. 
Table 4. Changes in physical fitness

(Mean \pm SD)

\begin{tabular}{|c|c|c|c|c|c|c|c|}
\hline \multirow{2}{*}{ Variables } & \multirow{2}{*}{ Groups } & \multicolumn{2}{|c|}{ Tests } & & \multirow{2}{*}{$\Delta \%$} & & \multirow{2}{*}{$p$} \\
\hline & & Pre & Post & & & & \\
\hline \multirow{2}{*}{$\begin{array}{l}\text { Left grip strength } \\
(\mathrm{kg})\end{array}$} & $\mathrm{TR}$ & $24.85 \pm 4.43$ & $28.38 \pm 3.17$ & $* *$ & 14.21 & \multirow{2}{*}{$\begin{array}{c}\text { Group } \\
\text { Test } \\
\text { Group } \times \text { Test }\end{array}$} & \multirow{2}{*}{$\begin{array}{l}.970 \\
.010^{+} \\
.004^{++}\end{array}$} \\
\hline & $\mathrm{CON}$ & $26.68 \pm 4.11$ & $26.44 \pm 4.93$ & & -0.90 & & \\
\hline \multirow{2}{*}{$\begin{array}{l}\text { Right grip strength } \\
(\mathrm{kg})\end{array}$} & $\mathrm{TR}$ & $26.55 \pm 4.65$ & $28.09 \pm 3.90$ & & 5.80 & \multirow{2}{*}{$\begin{array}{c}\text { Group } \\
\text { Test } \\
\text { Group } \times \text { Test }\end{array}$} & \multirow{2}{*}{$\begin{array}{l}.843 \\
.359 \\
.157\end{array}$} \\
\hline & $\mathrm{CON}$ & $27.20 \pm 4.41$ & $26.87 \pm 4.08$ & & -1.21 & & \\
\hline \multirow{2}{*}{$\begin{array}{l}\text { Sit-up } \\
\text { (rep) }\end{array}$} & $\mathrm{TR}$ & $15.93 \pm 11.37$ & $24.60 \pm 9.52$ & $* * *$ & 54.43 & \multirow{2}{*}{$\begin{array}{c}\text { Group } \\
\text { Test } \\
\text { Group } \times \text { Test }\end{array}$} & \multirow{2}{*}{$\begin{array}{l}.094 \\
.000^{+1+} \\
.000^{+1+}\end{array}$} \\
\hline & $\mathrm{CON}$ & $13.71 \pm 9.02$ & $14.68 \pm 9.27$ & & 7.08 & & \\
\hline \multirow{2}{*}{$\begin{array}{l}\text { Standing long jump } \\
(\mathrm{cm})\end{array}$} & $\mathrm{TR}$ & $121.53 \pm 18.96$ & $134.72 \pm 14.71$ & $* * *$ & 10.85 & \multirow{2}{*}{$\begin{array}{c}\text { Group } \\
\text { Test } \\
\text { Group } \times \text { Test }\end{array}$} & \multirow{2}{*}{$\begin{array}{l}.944 \\
.005^{++} \\
.018^{+}\end{array}$} \\
\hline & $\mathrm{CON}$ & $127.87 \pm 13.69$ & $129.18 \pm 18.73$ & & 1.02 & & \\
\hline \multirow{2}{*}{$\begin{array}{l}\text { Sit-and-reach } \\
(\mathrm{cm})\end{array}$} & $\mathrm{TR}$ & $14.18 \pm 7.70$ & $17.30 \pm 6.52^{\#}$ & $* *$ & 22.00 & \multirow{2}{*}{$\begin{array}{c}\text { Group } \\
\text { Test } \\
\text { Group } \times \text { Test }\end{array}$} & \multirow{2}{*}{$\begin{array}{l}.223 \\
.029^{+} \\
.004^{++}\end{array}$} \\
\hline & $\mathrm{CON}$ & $12.47 \pm 8.41$ & $11.99 \pm 8.69$ & & -3.85 & & \\
\hline \multirow{2}{*}{$\begin{array}{l}\text { One leg standing with eyes-closed } \\
(\mathrm{sec})\end{array}$} & $\mathrm{TR}$ & $17.96 \pm 13.28$ & $31.46 \pm 23.22$ & * & 75.17 & \multirow{2}{*}{$\begin{array}{c}\text { Group } \\
\text { Test } \\
\text { Group } \times \text { Test }\end{array}$} & \multirow{2}{*}{$\begin{array}{l}.253 \\
.060 \\
.035^{+}\end{array}$} \\
\hline & $\mathrm{CON}$ & $19.52 \pm 10.70$ & $18.70 \pm 13.19$ & & -4.20 & & \\
\hline \multirow{2}{*}{$\begin{array}{l}\mathrm{VO}_{2} \max \\
\left(\mathrm{ml} \cdot \mathrm{kg}^{-1} \cdot \mathrm{min}^{-1}\right)\end{array}$} & $\mathrm{TR}$ & $31.08 \pm 3.00$ & $33.57 \pm 3.27$ & $* * *$ & 8.01 & \multirow{2}{*}{$\begin{array}{c}\text { Group } \\
\text { Test } \\
\text { Group } \times \text { Test }\end{array}$} & \multirow{2}{*}{$\begin{array}{l}.730 \\
.000^{+1} \\
.000^{+1}\end{array}$} \\
\hline & $\mathrm{CON}$ & $32.32 \pm 1.85$ & $32.98 \pm 1.93$ & * & 2.04 & & \\
\hline
\end{tabular}

\#: Significant difference between two groups.

${ }^{* *} p<.05,{ }^{* *} p<.01^{* * *} p<.001$ : Significant difference between pre and post-test.

${ }^{+} p<.05,{ }^{++} p<.01,{ }^{+++} p<.001$ : Significant main effect and/or interaction.

Table 5. Changes in blood lipids

$(\mathrm{Mean} \pm \mathrm{SD})$

\begin{tabular}{|c|c|c|c|c|c|c|c|}
\hline \multirow{2}{*}{ Variables } & \multirow{2}{*}{ Groups } & \multicolumn{2}{|c|}{ Tests } & & \multirow{2}{*}{$\Delta \%$} & & \multirow{2}{*}{$p$} \\
\hline & & Pre & Post & & & & \\
\hline \multirow{2}{*}{$\begin{array}{l}\text { Total cholesterol } \\
\left(\mathrm{mg} \cdot \mathrm{dl}^{-1}\right)\end{array}$} & $\mathrm{TR}$ & $185.00 \pm 27.69$ & $167.81 \pm 19.77^{\#}$ & ** & -9.29 & \multirow{2}{*}{$\begin{array}{c}\text { Group } \\
\text { Test } \\
\text { Group } \times \text { Test }\end{array}$} & \multirow{2}{*}{$\begin{array}{l}.103 \\
.015^{+} \\
.043^{+}\end{array}$} \\
\hline & $\mathrm{CON}$ & $188.93 \pm 20.39$ & $187.26 \pm 16.27$ & & -0.88 & & \\
\hline \multirow{2}{*}{$\begin{array}{l}\text { Triglyceride } \\
\left(\mathrm{mg} \cdot \mathrm{dl}^{-1}\right)\end{array}$} & TR & $87.83 \pm 31.38$ & $62.28 \pm 17.79^{\#}$ & ** & -29.09 & \multirow{2}{*}{$\begin{array}{c}\text { Group } \\
\text { Test } \\
\text { Group } \times \text { Test }\end{array}$} & \multirow{2}{*}{$\begin{array}{l}.028^{+} \\
.076 \\
.025^{+}\end{array}$} \\
\hline & $\mathrm{CON}$ & $98.61 \pm 31.09$ & $101.86 \pm 48.57$ & & 3.30 & & \\
\hline \multirow{2}{*}{$\begin{array}{l}\text { Low density lipoprotein-cholesterol } \\
\left(\mathrm{mg} \cdot \mathrm{dl}^{-1}\right)\end{array}$} & $\mathrm{TR}$ & $120.67 \pm 24.44$ & $117.84 \pm 15.50$ & & -2.35 & \multirow{2}{*}{$\begin{array}{c}\text { Group } \\
\text { Test } \\
\text { Group } \times \text { Test }\end{array}$} & \multirow{2}{*}{$\begin{array}{l}.581 \\
.193 \\
.696\end{array}$} \\
\hline & $\mathrm{CON}$ & $126.67 \pm 26.13$ & $121.47 \pm 31.24$ & & -4.11 & & \\
\hline \multirow{2}{*}{$\begin{array}{l}\text { High density lipoprotein- cholesterol } \\
\left(\mathrm{mg} \cdot \mathrm{dl}^{-1}\right)\end{array}$} & $\mathrm{TR}$ & $56.58 \pm 5.89$ & $58.52 \pm 8.22^{\#}$ & & 3.43 & \multirow{2}{*}{$\begin{array}{c}\text { Group } \\
\text { Test } \\
\text { Group } \times \text { Test }\end{array}$} & \multirow{2}{*}{$\begin{array}{l}.013^{+} \\
.257 \\
.004^{+}\end{array}$} \\
\hline & $\mathrm{CON}$ & $50.92 \pm 11.85$ & $46.69 \pm 10.72$ & $* *$ & -8.31 & & \\
\hline
\end{tabular}

\#: Significant difference between two groups.

${ }^{* *} p<.01$, Significant difference between pre and post-test.

${ }^{+} p<.05,{ }^{++} p<.01$ : Significant main effect and/or interaction. 
Table 6. Changes in surrogate indices of insulin resistance

$(\mathrm{Mean} \pm \mathrm{SD})$

\begin{tabular}{|c|c|c|c|c|c|c|c|}
\hline \multirow{2}{*}{ Variables } & \multirow{2}{*}{ Groups } & \multicolumn{2}{|c|}{ Tests } & \multirow{2}{*}{\multicolumn{2}{|c|}{$\Delta \%$}} & & \multirow{2}{*}{$p$} \\
\hline & & Pre & Post & & & & \\
\hline \multirow{2}{*}{$\begin{array}{l}\text { Fasting plasma glucose } \\
\left(\mathrm{mg} \cdot \mathrm{dl}^{-1}\right)\end{array}$} & $\mathrm{TR}$ & $96.73 \pm 6.49$ & $89.67 \pm 7.53$ & $*$ & -7.30 & Group & .652 \\
\hline & $\mathrm{CON}$ & $93.11 \pm 5.25$ & $95.23 \pm 12.07$ & & 2.28 & Group $\times$ Test & $.040^{+}$ \\
\hline \multirow{2}{*}{$\begin{array}{l}\text { Fasting plasma insulin } \\
\left(\mu \mathrm{IU} \cdot \mathrm{ml}^{-1}\right)\end{array}$} & $\mathrm{TR}$ & $7.45 \pm 3.24$ & $5.18 \pm 2.84 \#$ & $* * *$ & -30.47 & Group & $.033^{+}$ \\
\hline & $\mathrm{CON}$ & $9.55 \pm 5.28$ & $10.01 \pm 5.92$ & & 4.82 & Group $\times$ Test & $.027^{+}$ \\
\hline \multirow{2}{*}{ HOMA-IR } & $\mathrm{TR}$ & $1.76 \pm 0.74$ & $1.18 \pm 0.69 \#$ & $* * *$ & -32.95 & Group & $.036^{+}$ \\
\hline & $\mathrm{CON}$ & $2.20 \pm 1.24$ & $2.50 \pm 1.85$ & 0 & 13.64 & Group $\times$ Test & $\begin{array}{l}.4 / 1 \\
.032^{+}\end{array}$ \\
\hline
\end{tabular}

HOMA-IR: homeostasis model of assessment for insulin resistance.

\#: Significant difference between two groups.

${ }^{*} p<.05,{ }^{* * *} p<.001$ : Significant difference between pre and post-test.

${ }^{+} p<.05$ : Significant main effect and/or interaction.

Table 7. Correlation coefficients among amount of change from pre-test to post-test of abdominal fat area, percent body fat, and $\mathrm{VO}_{2} \mathrm{max}$ variables in the training group

$(\mathrm{Mean} \pm \mathrm{SD})$

\begin{tabular}{|c|c|c|c|c|c|}
\hline & $\begin{array}{c}\triangle \text { Total abdominal } \\
\text { fat area }\end{array}$ & $\begin{array}{l}\triangle \text { Visceral } \\
\text { fat area }\end{array}$ & $\begin{array}{c}\triangle \text { Subcutaneous } \\
\text { fat area }\end{array}$ & $\begin{array}{l}\triangle \text { Percent } \\
\text { body fat }\end{array}$ & $\triangle \mathrm{VO}_{2} \max$ \\
\hline$\triangle$ Total abdominal fat area & - & $.841^{* *}$ & $.969^{* *}$ & $.648^{* *}$ & $-.727^{* *}$ \\
\hline$\triangle$ Visceral fat area & & - & $.682^{* *}$ & $.548^{*}$ & $-.583^{*}$ \\
\hline$\triangle$ Subcutaneous fat area & & & - & $.626^{* *}$ & $-.717^{* *}$ \\
\hline$\triangle$ Percent body fat & & & & - & -.445 \\
\hline$\triangle \mathrm{VO}_{2} \max$ & & & & & - \\
\hline
\end{tabular}

$\triangle$ : amount of change from pre-test to post-test: ${ }^{*} p<.05,{ }^{* *} p<.01$

\section{논 의}

\section{복부 지방의 변화}

복부 지 방량은 $\mathrm{BMI}$ 와 체지방률에 비하여 심혈관질 환을 예측하는데 있어서 훨씬 더 중요한 요인으로 인식된 다(Nordström et al., 2016). 복부 지방은 내장 지방과 피 하 지방으로 구분되며, 컴퓨터 단층촬영 (computed tomography: CT)을 통하여 TAFA, VFA, 그리고 $\mathrm{SFA}$ 로 측 정된다. (Ryo et al., 2014).

Zhang et al. (2015)은 다양한 강도로 운동을 실시한 결 과 고강도 간헐적 운동 트레이닝집단에서는 $\mathrm{VFA}$ 와 $\mathrm{SFA}$ 가 유의하게 감소된 반면, 중강도 운동집단에서는 $\mathrm{SFA}$
만 유의하게 감소되었다고 보고하였다. 고강도 인터벌 트 레이닝과 중강도 연속훈련을 16주간 실시한 Maillard et al. (2016)의 연구에서는 고강도 인터벌 트레이닝 집단에 서만 TAFA과 $\mathrm{VFA}$ 의 유의한 감소가 나타났다. 또한 12 주간 순환운동을 진행한 Kim et al.(2014)의 연구에서 도 운동집단의 $\mathrm{TAFA}$ 와 $\mathrm{SFA}$ 는 유의하게 감소되었고, $\mathrm{VFA}$ 역시 감소되는 경향을 보여 통제집단과 비교하여 복부지방의 전반적인 감소에 순환운동이 긍정적인 영향 을 준 것으로 나타났다.

복부 지방과 관련된 선행연구를 통하여 저강도 또는 중 강도 운동에 비해 고강도 운동 시 내장 지방 감소가 더 크 게 나타났다고 보고되었으며 (Slentz et al., 2005; Irving et al., 2008; Coker et al., 2009), 다수의 연구에서 중년 
비만 여성을 대상으로 운동중재 후 복부지방이 감소되는 것 으로 보고되었다(Park et al., 2003; Ismail et al., 2012; Maillard et al., 2018). 그러나 중년 비만 여성을 대상으 로 고강도 순환운동이 복부 지방, 특히 내장 지방에 미치 는 영향을 규명한 연구가 매우 부족하기 때문에, 이와 같 은 연구는 비만자를 대상으로 운동을 지도하는 현장에 큰 시사점을 던져줄 것으로 기대된다. 이에 이 연구에서는 중 년 비만 여성을 대상으로 HICT를 통한 복부 지방면적의 변화를 파악하기 위하여 타당도 높은 검사장비인 CT를 이용해서 복부 지방면적을 측정하였다. 그 결과 $\mathrm{TAFA}$, $\mathrm{VFA}, \mathrm{SFA}$, 그리고 $\mathrm{V} / \mathrm{S}$ 모두에서 집단과 검사의 상호작 용이 유의하게 나타났으며, 이 모든 변인이 운동집단에서 유의하게 감소되었다. 이 연구에서 중재한 순환운동은 유 산소운동과 저항성운동을 복합적으로 구성한 것이며, 고 강도로 진행되었기 때문에 복부 지방면적이 모두 유의하 게 감소된 것으로 해석된다. 아울러 운동집단의 모든 대 상자는 동일한 전문 트레이너 1인에게서 개인 트레이닝 (PT) 형식으로 운동지도를 받았기 때문에 더욱 일관성 있고 충실하게 운동 중재한 점도 복부 지방과 관련한 모 든 변인에서 매우 유의한 개선 결과를 도출할 수 있었던 이유가 된다고 판단된다.

\section{체격과 신체구성의 변화}

이 연구에서 12 주간 $\mathrm{HICT}$ 를 중재한 결과 운동집단 의 체중, $\mathrm{BMI}$, 체지방량, 그리고 체지방률이 유의하게 감소되었다. 이는 12 주간 실시한 HICT를 통하여 체중, $\mathrm{BMI}$, 그리고 체지방량이 유의하게 감소되었다고 보고한 Sperlich et al. (2017)의 연구 결과 및 12 주간의 유산소 성 순환운동을 통하여 체중, BMI, 그리고 체지방량이 유 의하게 감소되었다고 보고한 Contrò et al. (2017)의 연 구 결과와 일치한다. 이상의 결과들을 종합하여 규칙적인 고강도 순환운동이 체중과 체지방의 감소에 매우 효과적 이라고 정리할 수 있으며, 이는 순환운동 중 실시한 유산 소운동에 의하여 지방대사가 촉진되어 나타난 것으로 해 석된다.

그러나 기대와 달리 이 연구에서는 제지 방량의 유의한 증가가 나타나지는 않았다. 이와 관련하여 Dudgeon et al. (2016)은 운동을 통해 급격한 체중 감소가 나타날 경우 제지방량의 유의한 증가가 나타나지 않거나 오히려 감소 될 수도 있지만, 체중 대비 근력의 효율이 증가되기 때문
에 제지방량의 감소가 체력의 저하로 이어지지는 않는다 고 주장하였다. 이 연구에서도 운동집단의 체중이 $5.44 \%$ 감소되고 체지방량이 $12.3 \%$ 감소됨으로써 신체구성이 개선되었고, 제지방량이 $1.44 \%$ 감소되었지만 대부분의 근기능관련 체력수준이 유의하게 증가된 것으로 나타나 제지방량의 감소에 따른 부정적인 영향은 없었던 것으로 확인되었다. 제지방량의 유의한 증가를 위해서는 저항성 운동 후 충분한 단백질 섭취가 이루어져야 한다고 보고한 Devries \& Phillips(2015)의 연구 결과를 고려하여, 향 후 HICT 중 단백질 섭취 여부에 따른 제지방량의 변화를 보다 면밀하게 규명하는 후속 연구가 요청된다.

허리둘레는 복부 비만을 평가하고 대사증후군을 판단 하기 위한 기준으로 활용되어 왔고(Gierach et al., 2014), CT로 측정한 내장 지방면적과 상관관계가 높은 것으로 나타났으며 (Baria et al., 2014), 허리둘레의 감소만으로도 복부 내장 지방의 증가에 기인하여 생기는 각종 질병의 발병률을 낮추는 것으로 보고되었다(Moliner-Urdiales et al., 2013). 이 연구에서는 운동집단의 허리둘레와 WHR 이 유의하게 감소된 반면, 엉덩이둘레는 유의하게 변하지 않아 WHR의 감소가 주로 허리둘레의 감소에 의하여 나 타난 것으로 판단된다. 이와 관련하여 $\mathrm{Esan}(2018)$ 은 12 주간 저항성 순환운동을 실시한 결과 허리둘레와 $\mathrm{WHR}$ 이 유의하게 감소되었다고 보고하였고, Sanal et al. (2013) 은 12 주간 유산소운동을 실시한 결과 허리둘레와 엉덩이 둘레가 모두 유의하게 감소되었다고 보고하였다. 이 연구 에서 운동집단의 허리둘레가 유의하게 감소된 것은 $\mathrm{HICT}$ 중 실시한 유산소운동의 효과라고 판단되며, 엉덩이둘레 가 유의하게 감소되지 않은 것은 저항성운동, 특히 squat 동작을 실시한 결과 엉덩이 부위의 근육량이 유지되어 나 타난 것이라고 해석된다.

\section{체력의 변화}

이 연구에서는 HICT를 통한 체력의 개선 여부를 확 인하기 위하여 근력, 근지구력, 순발력, 유연성, 평형성, 그리고 심폐지구력을 평가하였다.

악력은 근력을 평가하기 위한 가장 일반적인 방법으로 서(Volaklis et al., 2015), 이 연구에서는 운동집단의 좌 악력이 유의하게 증가되었고 우악력은 증가되는 경향을 보였다. 이와 같은 결과는 운동을 통하여 근력이 향상되 었다고 보고한 선행연구(Sculthorpe et al., 2015)의 결 
과와 일치한다. 한편, 이 연구에서 좌악력만 유의하게 증 가한 이유는 평소 주사용 손에 비하여 악력이 낮은 다른 손의 경우 운동 트레이닝을 통한 악력의 향상 폭이 더 클 수 있다는 Guilherme et al.(2015)의 주장을 통하여 해 석할 수 있다.

이 연구에서는 근지구력을 평가하기 위하여 윗몸일으 키기를 실시하였으며, 그 결과 운동집단의 기록이 유의하 게 향상되었다. 근지구력의 향상을 위해서는 많은 반복 이 수반되는 운동이 효과적이라고 보고되었다(Solanki et al., 2015). 이 연구에서 중재한 HICT에 포함된 복부운동 은 정해진 시간 동안 많은 반복을 하는 형태로 진행되었 으며, 이와 같은 지속적이고 주기적인 반복운동을 통하여 복부의 근지구력이 개선되어 윗몸일으키기 기록이 향상 된 것으로 해석된다.

순발력은 짧은 시간 내에 최대의 힘을 발휘할 수 있는 능력으로서 순간적인 근 수축에 의해 일어나는 힘을 의미 한다(Konow et al., 2011). 이 연구에서 제자리멀리뛰기 를 실시하여 순발력을 평가한 결과 운동집단의 기록이 유 의하게 향상되었다. 이와 관련하여 Kang et al. (2012) 은 비만 여대생을 대상으로 순환운동을 실시한 결과 순 발력이 유의하게 향상되었다는 이 연구과 일치된 결과를 보고한 바 있다. 순발력의 향상을 위해서는 근력의 증가 와 함께 기능적 움직임이 향상되어야 하며(Konow et al., 2011), 이 연구의 운동집단 대상자가 실시한 체중부하를 이용한 유산소운동과 하지운동으로 인하여 하지근력과 근육간 협응력이 개선되어 순발력이 향상된 것으로 해석 된다.

이 연구에서 앉아윗몸앞으로굽히기를 실시하여 유연 성을 평가한 결과 운동집단의 기록이 유의하게 향상되었 다. 이와 관련하여 Kim et al. (2018)은 비만 여대생이 12 주간 순환운동을 실시한 결과 유연성이 유의하게 향상 되었다고 보고하였고, 폐경기 여성을 대상으로 12 주간 순 환운동을 실시한 Ogwumike et al. (2011)의 연구에서도 유연성이 유의하게 향상된 것을 확인할 수 있었다. 이 연 구에서 실시한 HICT에 포함된 저항성운동 동작은 주로 등장성 운동으로서 신장성 수축과 단축성 수축이 반복되 었으며, 이 중 신장성 수축으로 인한 동적 스트레칭 동작 이 유연성 향상에 도움을 준 것으로 판단된다.

이 연구에서는 평형성을 평가하기 위하여 눈감고외발 서기를 실시하였으며, 그 결과 운동집단의 기록이 유의하 게 향상되었다. 선행 연구에서 HICT에 따른 평형성의 변
화를 살펴본 경우가 거의 없어 비교에 제한적이며, 관련 연구를 살펴보면 de Camargo Smolarek et al.(2016)이 12 주간 저항성운동을 실시한 결과 평형성이 유의하게 향상되었다고 보고하여 이 연구의 결과와 유사하였다. 평 형성은 하지와 복부 주변 근육의 강화, 그리고 골반 주변 근육의 협응력 증가에 따라 나타난다고 주장한 Lord et al. (1996)의 연구를 고려할 때, 이 연구의 운동집단 대상 자가 실시한 체중부하를 이용한 유산소운동과 하지 및 복 부운동이 평형성의 향상에 공헌한 것으로 해석된다.

심폐지구력은 가장 대표적인 건강체력 요소로서, 심폐 지구력을 향상시키면 유산소운동능력을 개선하는 것은 물론 각종 대사질환과 심혈 관질환의 발병률을 감소시 키기 때문에 매우 큰 의미가 있다(Santos et al., 2012). 이 연구에서 YMCA 스텝테스트를 실시하여 심폐지구력 을 평가한 결과 운동집단의 기록이 유의하게 향상되었다. 이는 12 주간 실시한 $\mathrm{HICT}$ 운동 중 포함된 유산소운동 결과 나타난 것으로 판단된다. 한편, 이 연구의 통제집단 에서도 유의한 향상이 나타났지만, 이는 사전검사의 경험 에 따라 향상된 것일 뿐 운동집단의 향상도 $(8.01 \%)$ 와 통 제집단의 향상도 $(2.04 \%)$ 를 비교해 볼 때 $\mathrm{HICT}$ 의 효과 가 유의하게 나타났다고 해석할 수 있다. 집단과 검사의 상호작용이 유의하게 $(p<.001)$ 나타났던 점도 이와 같은 해석을 뒷받침한다.

\section{혈중 지질의 변화}

혈중 지질 특성은 신진 대사에 다양한 영향을 미치기 때문에 혈중 지질 농도를 정상범위로 관리하는 것이 매 우 중요하다(Vaziri \& Liang, 2004). 일반적으로 운동 트레이닝을 통하여 $\mathrm{TC}, \mathrm{TG}$, 그리고 $\mathrm{LDL}-\mathrm{C}$ 가 감소되고, $\mathrm{HDL}-\mathrm{C}$ 가 증가되는 것으로 보고되었다. 이와 관련하여 Paoli et al. (2013)은 중년 남성을 대상으로 HICT를 실 시한 결과 TC, TG, LDL-C, 그리고 HDL-C가 유의하게 개선되었다고 보고하였고, Hagner et al. (2009)은 12 주간 실시한 중강도의 지구력 운동을 통하여 중년 여성 의 $\mathrm{TC}, \mathrm{TG}, \mathrm{LDL}-\mathrm{C}$, 그리고 $\mathrm{HDL}-\mathrm{C}$ 가 유의하게 개선되 었다고 보고하면서 약물치료에 의존하지 않고 운동만을 통하여 혈중 지질이 개선 될 수 있다고 주장하였다. 이 연 구에서도 운동집단의 $\mathrm{TC}$ 와 $\mathrm{TG}$ 가 유의하게 감소되고, $\mathrm{HDL}-\mathrm{C}$ 에서 집단과 검사의 상호작용이 유의하게 나타나 선행 연구과 유사한 결과를 보였다. $\mathrm{HDL}-\mathrm{C}$ 의 경우 통제 
집단에서는 유의하게 $(p<.01)$ 감소된 반면 운동집단에서 $3.43 \%$ 증가됨으로써 집단과 검사의 상호작용이 유의하 게 나타나 $(p=.004)$ 운동 트레이닝의 효과가 유의했다 고 해석할 수 있다.

한편, 이 연구에서는 운동집단과 통제집단 모두에서 $\mathrm{LDL}-\mathrm{C}$ 의 유의한 변화가 나타나지 않았다. 전술한 바와 같이 $\mathrm{LDL}-\mathrm{C}$ 가 많은 선행 연구에서 운동 트레이닝을 통 하여 감소된 것으로 나타났지 만, 모든 연구에서 동일한 결과가 나온 것은 아니었다. 이와 관련하여 $\mathrm{Ho}$ et al. (2012)은 12주간 비만 남녀를 대상으로 순환운동을 실 시한 결과 $\mathrm{LDL}-\mathrm{C}$ 의 유의한 변화가 없었다고 보고하였 고, Franklin et al.(2015)도 8주간 폐경전 비만 여성을 대상으로 순환운동을 실시한 결과 $\mathrm{LDL}-\mathrm{C}$ 의 유의한 변 화가 없었다고 보고하였다. Goldberg et al.(2011)은 운 동을 통하여 감소되는 체중 $1 \mathrm{~kg}$ 당 LDL-C 가 약 0.8 $\mathrm{mg} \cdot \mathrm{dl}^{-1}$ 감소된다고 보고하였으며, 이는 운동 자체만으로 는 $\mathrm{LDL}-\mathrm{C}$ 수치의 개선에 제한적이라는 것을 의미한다. 이 연구에서는 운동집단의 체중이 $3.8 \mathrm{~kg}$ 감소되고 $\mathrm{LDL}-$ $\mathrm{C}$ 가 $2.83 \mathrm{mg} \cdot \mathrm{dl}^{-1}$ 감소되어 Goldberg et al.(2011)의 주 장과 비슷한 양상을 보였다. 그러나 이와 같은 장기간의 고강도 순환운동을 지속할 경우 노화로 인한 혈중 지질의 부정적인 변화를 예방할 수 있기 때문에 임상적인 의미가 크다(Kim et al., 2014). 이에 더하여 Tambalis et al. (2009)은 운동 트레이닝이 TC와 TG의 감소에는 큰 역 할을 하지만, $\mathrm{LDL}-\mathrm{C}$ 는 운동만으로는 항상 변화되지는 않는다고 보고하여 이 연구의 결과를 뒷받침하였다. 향 후 다양한 유형의 운동 및 다양한 강도의 운동에 따른 혈 중 지질 특성의 변화를 보다 면밀하게 분석하는 후속 연 구가 요청된다.

\section{인슐린 저항성의 변화}

인슐린 저항성 (insulin resistance)은 인슐린이 혈관 내 포도당을 근육이나 간으로 이동시키지 못하고, 인슐린의 기 능이 떨어지며 그 농도가 증가되는 상태이다 (Goodpaster et al., 2003). 이 연구에서는 12주간 실시한 HICT가 인 슐린 저항성에 미치는 영향을 파악하기 위하여 인슐린 저 항성 지표인 $\mathrm{FPG}, \mathrm{FPI}$, 그리고 $\mathrm{HOMA}-\mathrm{IR}$ 을 측정하였 으며, 운동집단의 FPG, FPI, 그리고 HOMA-IR 모두 유 의하게 감소되어 인슐린 저항성이 개선된 것으로 나타났 다. 이와 관련하여 AminiLari et al. (2017)은 중년 당뇨
병 여성을 대상으로 다양한 유형의 운동을 중재한 연구에 서 유산소운동집단과 복합운동집단에서 $\mathrm{FPG}$ 가 유의하 게 감소되었고, $\mathrm{HOMA}-\mathrm{IR}$ 은 저항성 운동집단, 유산소운 동집단, 그리고 복합운동집단 모두에서 유의하게 감소 되었으며, 특히 복합운동집단에서 가장 큰 폭의 감소를 보였다고 보고하였다. 이와 같은 결과는 인슐린 저항성 지표가 운동의 유형에 따라 다른 정도로 개선된다는 것 을 의미하며, 이 연구에서 12 주간 유산소운동과 저항성 운동을 복합적으로 중재하였기 때문에 인슐린 저항성 지 표가 모두 유의하게 개선되는데 큰 영향을 미친 것으로 판단된다.

이 연구에서는 운동집단의 체중이 $5.44 \%$, 체지방량이 $13.30 \%$, 그리고 허리둘레가 $7.75 \%$ 감소된 것을 고려 할 때, 이 연구에서 중재한 HICT가 체내 지방대사를 촉 진하고 혈중 유리지방산 농도를 증가시켰을 것으로 유추 되며, 이를 통하여 탄수화물 대사에 대한 의존도를 줄이 고 인슐린과 세포의 인슐린 수용체와의 결합능력을 향상 시켜 인슐린 저항성을 개선시킨 것으로 판단된다(Samuel \& Shulman, 2016). 이상의 결과는 HICT가 중년 비만 여성의 당뇨병을 예방·개선하는데 효과적이라는 것을 의 미하지만, 운동 트레이닝에 의하여 나타난 인슐린 저항성 의 개선 효과가 운동을 중지하면 단기간에 사라질 수 있 다는 Le et al. (2016)의 주장을 고려하여 이와 같은 효과 를 지속할 수 있도록 운동을 생활화 하는 노력과 관리가 더욱 중요할 것이다.

\section{종속변인 간 상관관계 분석}

이 연구에서 각 종속변인의 변화량 간의 관계를 알아 보기 위하여 상관분석을 실시한 결과 TAFA, VFA, 그리 고 $\mathrm{SFA}$ 가 체지방률과 유의한 정적 상관관계를 보인 반 면, $\mathrm{VO}_{2} \mathrm{max}$ 와는 유의한 부적 상관관계를 보였으며, 다 른 변인에서는 유의한 상관관계가 나타나지 않았다.

체지방률은 복부 지방과 관련이 매우 크며, 높은 수준 의 체지방률은 복부 지방 증가의 직접적인 원인으로 작 용한다(Irving et al., 2008). 또한, 복부 지방은 체력에 부 정적인 영향을 가져오는데, 특히 $\mathrm{VO}_{2} \mathrm{max}$ 의 수준에 매 우 부정적인 영향을 미친다(Wong et al., 2004). 이 연구 의 결과와 선행 연구의 보고를 종합해보면, 중년여성의 과도한 체지방률의 증가는 복부 지방의 증가와 함께 체 력수준의 감소를 초래하며. 운동 트레이닝을 통하여 유사 
한 유형으로 개선된다고 정리할 수 있다.

\section{결 론}

이 연구의 목적은 12 주간의 고강도 순환운동이 중년 비만 여성의 복부 지방, 신체구성, 체력, 혈중 지질, 그리 고 인슐린 저항성에 미치는 영향에 대해 규명하는 것이었 다. 이 연구에서 얻은 결과를 요약하여 기술하면 다음과 같다.

1. 운동집단의 $\mathrm{TAFA}, \mathrm{VFA}, \mathrm{SFA}$, 그리고 $\mathrm{V} / \mathrm{S}$ 가 유 의하게 감소되었다.

2. 운동집단의 체중, $\mathrm{BMI}$, 체지방량, 체지방률, 허리 둘레, 그리고 $\mathrm{WHR}$ 이 유의하게 감소되었다.

3. 운동집단의 근력, 근지구력, 순발력, 유연성, 평형 성, 그리고 심폐지구력이 유의하게 향상되었다.

4. 운동집단의 $\mathrm{TC}$ 와 $\mathrm{TG}$ 가 유의하게 감소되었다.

5. 운동집단의 FPG, FPI, 그리고 HOMA-IR이 유의 하게 감소되었다.

이상의 결과를 종합해 보면, 12 주간 실시한 고강도 순 환운동이 중년 여성의 복부 지방, 신체구성, 체력, 혈중 지질, 그리고 인슐린 저항성의 개선에 효과적이었다고 결 론지을 수 있다. 이 연구의 목적은 유산소운동과 저항성 운동으로 구성되어 있는 고강도 복합 순환운동의 효과 를 규명하는 것이었지만, 단일 운동 중재집단이 없어 복 합 운동 중재의 필요성과 효과를 개관적으로 비교하는데 제한점이 있었다. 향후 각종 생활습관병의 원인이 되는 복부 지방에 대한 다양한 강도별 운동 트레이닝의 효과 를 비교하는 후속 연구와 복합 운동과 단일 운동의 효과 를 비교하는 후속 연구가 요청된다.

\section{참고문헌}

American College of Sports Medicine (2009). American college of sports medicine position stand. Progression models in resistance training for healthy adults. Medicine and Science in Sports and Exercise, 41(3), 687-708.

AminiLari, Z., Fararouei, M., Amanat, S., Sinaei, E.,
Dianatinasab, S., AminiLari, M., Daneshi, N., \& Dianatinasab, M. (2017). The effect of 12 weeks aerobic, resistance, and combined exercises on omentin-1 levels and insulin resistance among type 2 diabetic middle-aged women. Diabetes and Metabolism Journal, 41(3), 205-212.

Baria, F., Kamimura, M. A., Aoike, D. T., Ammirati, A., Leister Rocha, M., de Mello, M. T., \& Cuppari, L. (2014). Randomized controlled trial to evaluate the impact of aerobic exercise on visceral fat in overweight chronic kidney disease patients. Nephrology Dialysis Transplantation, 29(4), 857-864.

Coker, R. H., Williams, R. H., Kortebein, P. M., Sullivan, D. H., \& Evans, W. J. (2009). Influence of exercise intensity on abdominal fat and adiponectin in elderly adults. Metaboilc Syndrome and Related Disorders, 7(4), 363-368.

Contrò, V., Bianco, A., Cooper, J., Sacco, A., Macchiarella, A., Traina, M., \& Proia, P. (2017). Effects of different circuit training protocols on body mass, fat mass and blood parameters in overweight adults. Journal of Biological ResearchBollettino Della Società Italiana di Biologia Sperimentale, 90(1), 10-12.

de Camargo Smolarek, A., Ferreira, L. H. B., Mascarenhas, L. P. G., McAnulty, S. R., Varela, K. D., Dangui, M. C., de Barros, M. P., Utter, A. C., \& Souza-Junior, T. P. (2016). The effects of strength training on cognitive performance in elderly women. Clinical Interventions in Aging, 11, 749-754.

Devries, M. C. \& Phillips, S. M. (2015). Supplemental protein in support of muscle mass and health: Advantage whey. Journal of Food Science, 80(S1), A8-A15.

Dudgeon, W. D., Kelley, E. P., \& Scheett, T. P. (2016). In a single-blind, matched group design: Branched-chain amino acid supplementation and resistance training maintains lean body mass during a caloric restricted diet. Journal of the International Society of Sports Nutrition, 13(1), 1-10.

Esan, J. A. (2018). Effect of Circuit Strength Training Programme on Waist-to-Hip Ratio of College Students. Cypriot Journal of Educational Sciences, 13(3), 340-348.

Franklin, N. C., Robinson, A. T., Bian, J. T., Ali, M. M., Norkeviciute, E., McGinty, P., \& Phillips, S. A. (2015). Circuit resistance training attenuates acute exertion-induced reductions in arterial function but not inflammation in obese women. Metabolic Syndrome and Related Disorders, 13(5), 227-234.

Gierach, M., Gierach, J., Ewertowska, M., Arndt, A., \& Junik, R. (2014). Correlation between body mass index and waist circumference in patients with metabolic syndrome. ISRN 
Endocrinology, 2014, 1-6.

Goldberg, A. C., Hopkins, P. N., Toth, P. P., Ballantyne, C. M., Rader, D. J., Robinson, J. G., Daniels, S. R., Gidding, S. S., de Ferranti, S. D., Ito, M. K., McGowan, M. P., Moriarty, P. M., Cromwell, W. C., Ross, J. L., \& Ziajka, P. E. (2011). Familial hypercholesterolemia: Screening, diagnosis and management of pediatric and adult patients: Clinical guidance from the National Lipid Association Expert Panel on Familial Hypercholesterolemia. Journal of Clinical Lipidology, 5(3), S1-S8.

Golding, L. A. (2000). YMCA Fitness Testing and Assessment Manual. Human Kinetics: Champaign, IL.

Goodpaster, B. H., Katsiaras, A., \& Kelley, D. E. (2003). Enhanced fat oxidation through physical activity is associated with improvements in insulin sensitivity in obesity. Diabetes, 52(9), 2191-2197.

Guilherme, J., Garganta, J., Graça, A., \& Seabra, A. (2015). Influence of non-preferred foot technical training in reducing lower limbs functional asymmetry among young football players. Journal of Sports Sciences, 33(17), 1790-1798.

Hagner, W., Hagner-Derengowska, M., Wiacek, M., \& Zubrzycki, I. Z. (2009). Changes in level of VO2max, blood lipids, and waist circumference in the response to moderate endurance training as a function of ovarian aging. Menopause, 16(5), 1009-1013.

Ho, S. S., Dhaliwal, S. S., Hills, A. P., \& Pal, S. (2012). The effect of 12 weeks of aerobic, resistance or combination exercise training on cardiovascular risk factors in the overweight and obese in a randomized trial. BMC Public Health, 12(1), 704-713.

Irving, B. A., Davis, C. K., Brock, D. W., Weltman, J. Y., Swift, D., Barrett, E. J., Gaesser, G. A., \& Weltman, A. (2008). Effect of exercise training intensity on abdominal visceral fat and body composition. Medicine and Science in Sports and Exercise, 40(11), 1863-1872.

Ismail, I., Keating, S. E., Baker, M. K., \& Johnson, N. A. (2012). A systematic review and meta-analysis of the effect of aerobic vs. resistance exercise training on visceral fat. Obesity Reviews, 13(1), 68-91.

Kang, H. J., Lee, Y. S., Park, D. S., \& Kang, D. H. (2012). Effects of 12-week circuit weight training and aerobic exercise on body composition, physical fitness, and pulse wave velocity in obese collegiate women. Soft Computing, 16(3), 403-410.

Kim, H. J., Kang, C. K., Park, H., \& Lee, M. G. (2014). Effects of vitamin D supplementation and circuit training on indices of obesity and insulin resistance in T2D and vitamin $\mathrm{D}$ deficient elderly women. Journal of Exercise Nutrition and Biochemistry, 18(3), 249-257.

Kim, J. W., Ko, Y. C., Seo, T. B., \& Kim, Y. P. (2018). Effect of circuit training on body composition, physical fitness, and metabolic syndrome risk factors in obese female college students. Journal of Exercise Rehabilitation, 14(3), 460-465.

Kim, Y. Y., Lim, S., Choi, S. M., \& Lee, M. G. (2012). Effects of 12 weeks of aerobic and resistance training on abdominal fat, physical fitness, adipokines, and inflammatory markers in female elderly patients with type 2 diabetes. Korean Journal of Sport Science, 23(3), 489-501.

Klika, B. \& Jordan, C. (2013). High-intensity circuit training using body weight: Maximum results with minimal investment. ACSM's Health and Fitness Journal, 17(3), 8-13.

Konow, N., Azizi, E., \& Roberts, T. J. (2011). Muscle power attenuation by tendon during energy dissipation. Proceedings of the Royal Society B: Biological Sciences, 279(1731), 1108-1113.

Korea Institute of Sport Science (2014). Report for Development of Model of Fitness Certification Centers.

Le, S., Mao, L., Lu, D., Yang, Y., Tan, X., Wiklund, P., \& Cheng, S. (2016). Effect of aerobic exercise on insulin resistance and central adiposity disappeared after the discontinuation of intervention in overweight women. Journal of Sport and Health Science, 5(2), 166-170.

Lee, M. G., Park, K. S., Kim, D. U., Choi, S. M., \& Kim, H. J. (2012). Effects of high-intensity exercise training on body composition, abdominal fat loss, and cardiorespiratory fitness in middle-aged Korean females. Applied Physiology, Nutrition, and Metabolism, 37(6), 1019-1027.

Lee, O., Kim, S. S., Kim, Y. S., Son, H. J., Kim, Y. M., \& Choi, B. Y. (2008). Correlation between YMCA step-test and maximum oxygen consumption $\left(\mathrm{VO}_{2} \mathrm{max}\right)$ as measurement tools for cardiorespiratory. Epidemiology and Health, 30(1), 73-81.

Lizcano, F. \& Guzmán, G. (2014). Estrogen deficiency and the origin of obesity during menopause. BioMed Research International, 2014.

Lord, S. R., Ward, J. A., \& Williams, P. (1996). Exercise effect on dynamic stability in older women: A randomized controlled trial. Archives of Physical Medicine and Rehabilitation, 77(3), 232-236.

Maillard, F., Pereira, B., \& Boisseau, N. (2018). Effect of highintensity interval training on total, abdominal and visceral 
fat mass: A meta-analysis. Sports Medicine, 48(2), 269-288. Maillard, F., Rousset, S., Pereira, B., Traore, A., Del Amaze, P. D. P., Boirie, Y., Duclos, M., \& Boisseau, N. (2016). Highintensity interval training reduces abdominal fat mass in postmenopausal women with type 2 diabetes. Diabetes and Metabolism, 42(6), 433-441.

Matthews, D. R., Hosker, J. P., Rudenski, A. S., Naylor, B. A., Treacher, D. F., \& Turner, R. C. (1985). Homeostasis model assessment: Insulin resistance and $\beta$-cell function from fasting plasma glucose and insulin concentrations in man. Diabetologia, 28(7), 412-419.

Ministry of Culture, Sports and Tourism (2017). Investigation of Status of National Physical Fitness.

Moliner-Urdiales, D., Artero, E. G., Lee, D. C., España-Romero, V., Sui, X., \& Blair, S. N. (2013). Body adiposity index and all-cause and cardiovascular disease mortality in men. Obesity, 21(9), 1870-1876.

National Health Insurance Service (2017). Annual Report for Statistics of Health Screening in 2016.

Nordström, A., Hadrévi, J., Olsson, T., Franks, P. W., \& Nordström, P. (2016). Higher prevalence of type 2 diabetes in men than in women is associated with differences in visceral fat mass. The Journal of Clinical Endocrinology and Metabolism, 101(10), 3740-3746.

Ogwumike, O. O., Arowojolu, A. O., \& Sanya, A. O. (2011). Effects of a 12-week endurance exercise program on adiposity and flexibility of Nigerian perimenopausal and postmenopausal women. Nigerian Journal of Physiological Sciences, 26(2), 199-206.

Park, S. K., Park, J. H., Kwon, Y. C., Kim, H. S., Yoon, M. S., \& Park, H. T. (2003). The effect of combined aerobic and resistance exercise training on abdominal fat in obese middle-aged women. Journal of Physiological Anthropology and Applied Human Science, 22(3), 129-135.

Paoli, A., Pacelli, Q. F., Moro, T., Marcolin, G., Neri, M., Battaglia, G., Sergi, G., Bolzetta, F., \& Bianco, A. (2013). Effects of high-intensity circuit training, low-intensity circuit training and endurance training on blood pressure and lipoproteins in middle-aged overweight men. Lipids in Health and Disease, 12(1), 131-138.

Romero-Arenas, S., Martínez-Pascual, M., \& Alcaraz, P. E. (2013). Impact of resistance circuit training on neuromuscular, cardiorespiratory and body composition adaptations in the elderly. Aging and Disease, 4(5), 256-263.

Ryo, M., Kishida, K., Nakamura, T., Yoshizumi, T., Funahashi,
T., \& Shimomura, I. (2014). Clinical significance of visceral adiposity assessed by computed tomography: A Japanese perspective. World Journal of Radiology, 6(7), 409-416.

Samuel, V. T. \& Shulman, G. I. (2016). The pathogenesis of insulin resistance: Integrating signaling pathways and substrate flux. The Journal of Clinical Investigation, 126(1), 12-22.

Sanal, E., Ardic, F., \& Kirac, S. (2013). Effects of aerobic or combined aerobic resistance exercise on body composition in overweight and obese adults: Gender differences. A randomized intervention study. European Journal of Physical Rehabilitation and Medicine, 49(1), 1-11.

Santos, D. A., Silva, A. M., Baptista, F., Santos, R., Gobbo, L. A., Mota, J., \& Sardinha, L. B. (2012). Are cardiorespiratory fitness and moderate-to-vigorous physical activity independently associated to overweight, obesity, and abdominal obesity in elderly? American Journal of Human Biology, 24(1), 28-34.

Sculthorpe, N., Herbert, P., \& Grace, F. M. (2015). Lowfrequency high intensity interval training is an effective method to improve muscle power in lifelong sedentary aging men: A randomized controlled trial. Journal of the American Geriatrics Society, 63(11), 2412-2413.

Slentz, C. A., Aiken, L. B., Houmard, J. A., Bales, C. W., Johnson, J. L., Tanner, C. J., Duscha, B. D. \& Kraus. W. E. (2005). Inactivity, exercise, and visceral fat. STRRIDE: A randomized, controlled study of exercise intensity and amount. Journal of Applied Physiology, 99(4), 1613-1618.

Solanki, R., Bhise, A., Shukla, Y., \& Prabhakar, M. (2015). Effects of high intensity circuit training using body weight on aerobic fitness and muscular endurance in college students. Physiotherapy, 101, e1418-e1419.

Sperlich, B., Wallmann-Sperlich, B., Zinner, C., Von Stauffenberg, V., Losert, H., \& Holmberg, H. C. (2017). Functional highintensity circuit training improves body composition, peak oxygen uptake, strength, and alters certain dimensions of quality of life in overweight women. Frontiers in Physiology, $8,172-180$.

Takeshima, N., Rogers, M. E., Islam, M. M., Yamauchi, T., Watanabe, E., \& Okada, A. (2004). Effect of concurrent aerobic and resistance circuit exercise training on fitness in older adults. European Journal of Applied Physiology, 93(1), 173-182.

Tambalis, K., Panagiotakos, D. B., Kavouras, S. A., \& Sidossis, L. S. (2009). Responses of blood lipids to aerobic, resistance, and combined aerobic with resistance exercise train- 
ing: A systematic review of current evidence. Angiology, 60(5), 614-632.

Vaziri, N. D. \& Liang, K. (2004). ACAT inhibition reverses LCAT deficiency and improves plasma HDL in chronic renal failure. American Journal of Physiology-Renal Physiology, 287(5), F1038-F1043.

Volaklis, K. A., Halle, M., \& Meisinger, C. (2015). Muscular strength as a strong predictor of mortality: A narrative review. European Journal of Internal Medicine, 26(5), 303-310.

WHO (2018). Obesity and Overweight.

Willis, L. H., Slentz, C. A., Bateman, L. A., Shields, A. T., Piner, L. W., Bales, C. W., Houmard, J. A., \& Kraus, W. E. (2012). Effects of aerobic and/or resistance training on body mass and fat mass in overweight or obese adults. American
Journal of Physiology-Heart and Circulatory Physiology, 113(12), 1831-1837.

Wong, S. L., Katzmarzyk, P. T., Nichaman, M. Z., Church, T. S., Blair, S. N., \& Ross, R. (2004). Cardiorespiratory fitness is associated with lower abdominal fat independent of body mass index. Medicine and Science in Sports and Exercise, 36(2), 286-291.

Zhang, H., K Tong, T., Qiu, W., Wang, J., Nie, J., \& He, Y. (2015). Effect of high-intensity interval training protocol on abdominal fat reduction in overweight Chinese women: A randomized controlled trial. Kinesiology: International Journal of Fundamental and Applied Kinesiology, 47(1), 5766.

\title{
12 주간의 고강도 순환운동이 중년 비만 여성의 복부 지방, 체력, 혈중 지질 및 인슐린 저항성에 미치는 영향
}

\author{
박원범 · 조현석 · 이만균(경희대학교)
}

〔목적〕 이 연구의 목적은 중년 비만 여성을 대상으로 12 주간의 고강도 순환운동 (high intensity circuit training: HICT)이 복부 지방, 신체구성, 체력, 혈중 지질, 그리고 인슐린 저항성에 미치는 영향을 규명하는 것 이다. (방법) 체지방률이 $30 \%$ 이상이고, 연령이 32 48세인 중년 비만 여성 30명을 선정하여 HICT에 참여 하는 운동집단과 통제집단에 각각 15 명씩 무선할당 하였다. 운동집단의 대상자는 저항성운동과 유산소운동으 로 구성된 $\mathrm{HICT}$ 를 회당 40 분, 주 3 회, 12 주간 실시한 반면, 통제집단의 대상자는 동일한 중재 기간 동안 평소 의 생활습관을 그대로 유지하도록 하였다. 복부 지방, 신체구성, 체력, 혈중 지질, 그리고 인슐린 저항성과 관련 된 종속변인을 측정한 후, 반복 이원변량분석을 이용하여 두 집단 간에, 그리고 사점검사와 사후검사 간에 비 교하였다. (결과〕 이 연구에서 얻은 주요 결과는 다음과 같다. 1) 운동집단의 총복부 지방면적, 내장지방면적, 피하지방면적, 그리고 내장지방면적/복부 지방면적 비율이 유의하게 감소되었다. 2) 운동집단의 체중, 체질량 지수, 체지방량, 체지방률, 허리둘레, 그리고 허리엉덩이둘레 비율이 유의하게 감소되었다. 3) 운동집단의 근 력, 근지구력, 순발력, 유연성, 평형성, 그리고 심폐지구력이 유의하게 향상되었다. 4) 운동집단의 총콜레스테 롤과 중성지방이 유의하게 감소되었다. 5) 운동집단의 공복 혈당, 공복 인슐린, 그리고 HOMA-IR이 유의하 게 감소되었다. 〔결론) 이 연구에서 얻은 결과를 종합해볼 때, 12 주간 실시한 HICT는 복부 지방의 감소, 신체 구성의 개선, 체력의 향상, 그리고 혈중 지질과 인슐린 저항성의 개선에 공헌한 것으로 결론지을 수 있다.

주요어: 고강도 운동, 순환운동 트레이닝, 복부 지방, 혈중 지질, 인슐린 저항성 